\title{
THE INFLUENCE OF STEAM DRYING PROCESS ON COMBUSTION BEHAVIOR OF INDONESIAN LOW-RANK COALS
}

\author{
PENGARUH PROSES PENGERINGAN UAP TERHADAP SIFAT \\ PEMBAKARAN BATUBARA PERINGKAT RENDAH INDONESIA
}

\author{
DATIN F. UMAR, SUGANAL, IKA MONIKA, GANDHI K. HUDAYA and DAHLIA DINIYATI \\ Research and Development Centre for Mineral and Coal Technology \\ Jalan Jenderal Sudirman 623 Bandung 40211 \\ Ph. (+62 22) 6030483, Fax. (+62 22) 6003373 \\ e-mail: datin.umar@esdm.go.id
}

\begin{abstract}
Steam drying process of the Low Rank Coals (LRCs) has been conducted to produce coal which is comparable with the High Rank Coal (HRC). Characterization of the raw and dried coals was carried out through proximate, ultimate, calorific value, Fourier Transform Infrared (FTIR) spectroscopy and Thermo Gravimetry-Differential Thermal Analysis (TG-DTA) to study the combustion behavior of the coals. This study used Indonesian low rank coals coming from Tabang (TKK coal) and Samurangau (SP coal), East Kalimantan. The results indicate that the calorific value of the dried coals increases significantly due to the decrease in moisture content of the coal. The FTIR spectrums show that the methylene-ethylene $\left(\mathrm{R}_{\mathrm{CH}} / \mathrm{CH}_{2}\right)$ and aromaticity-aliphaticity ratios (Rar/al) of the dried coals increased while the ratio of $\mathrm{R}_{\mathrm{cO} / \mathrm{ar}}$ decreased which reflect that the rank of the coals increased equivalent to the high rank coal (bituminous). Meanwhile, the TG-DTA indicates that the ignition temperature (Tig) and combustion rate (Rmax) of the dried coals increased. This analysis expresses that the dried coals produced by steam drying process have better combustion behavior due to the higher calorific value than those of the raw coals.
\end{abstract}

Keywords: low rank coal, drying, calorific value, moisture, combustion.

\begin{abstract}
ABSTRAK
Proses pengeringan uap terhadap batubara peringkat rendah telah dilakukan untuk menghasilkan batubara yang setara dengan batubara peringkat tinggi. Karakterisasi batubara sebelum dan setelah proses pengeringan dilakukan melalui analisis proksimat, ultimat, nilai kalor, spektroskopi Fourier Transform Infrared (FTIR) dan Thermo Gravimetry-Differential Thermal Analysis (TG-DTA) untuk mempelajari sifat pembakaran batubara tersebut. Penelitian dilakukan menggunakan percontoh batubara peringkat rendah berasal dari daerah Tabang (batubara TKK) dan Samurangau (batubara SP), Kalimantan Timur. Hasilnya menunjukkan bahwa nilai kalor batubara hasil proses naik secara signifikan karena turunnya kadar air batubara tersebut. Spektra FTIR menunjukkan bahwa rasio metilen-etilen $\left(R_{\mathrm{CH} / \mathrm{CH} 2}\right)$ dan aromatisitialifatisiti $\left(R_{\text {ar/al }}\right)$ batubara hasil proses meningkat dan rasio $R_{c o / a r}$ turun yang menunjukkan bahwa peringkat batubara tersebut meningkat setara dengan batubara peringkat tinggi (bituminus). Sementara hasil TGDTA menunjukkan bahwa temperatur pembakaran awal (Tig) dan laju pembakaran (Rmax) batubara hasil proses pengeringan meningkat. Analisis tersebut menunjukkan bahwa batubara hasil proses pengeringan uap mempunyai sifat pembakaran yang lebih baik karena mempunyia nilai kalor yang lebih tinggi dibandingkan dengan batubara wantahnya.
\end{abstract}

Kata kunci: batubara peringkat rendah, pengeringan, nilai kalor, air lembab, pembakaran.

\section{INTRODUCTION}

Indonesia has a large amount of low rank coal (LRC) which includes lignite, brown coals and sub-bituminous coals. The LRC deposits are quite widespread throughout the archipelago (Wafid, 2019). Because of its young Tertiary age, most of the LRC occurs 
closed to the surface and has relatively homogenous layers, which make it easy and cheap to be exploited. The LRC was previously seen as uneconomical to be extracted and not feasible source of fuel because of its high moisture content, low heating values and high spontaneous combustion tendency (Sakaguchi et al., 2008; Fei et al., 2009; Rao et al., 2015). The fact that Indonesian coal industry has made a strong positive impact on the national economy. Coal producers have led to search new ways to exploit the LRC and find the new routes to bring the fuel to the market. One of the methods is to dry and upgrade the LRC before shipment. The technology increases the added value of the coal, for both export and domestic markets, stabilizes coal quality feed for power generation and other industries, increases combustion efficiency and reduces $\mathrm{CO}_{2}$ emission (Yu et al., 2013).

The main objective of the upgrading technologies is to reduce the moisture content and eliminate the impurities so that the calorific value of the coal increases to be more in line with that of high-grade coal (Ge et al., 2015). The technology is expected to develop clean, affordable, and sustainable energy supply in the country, as well as simultaneously helping transportation issues in its chain supply.

In the past studies, some researchers have investigated and discussed several coal upgrading technologies and developed upgraded brown coal (UBC) process as pretreatment of brown coal liquefaction (BCL) based on slurry dewatering process (Deguchi, Shigehisa and Shimasaki, 1999; Shigehisa et al., 2000; Umar, Usui and Daulay, 2005). The condition of process at a temperature of about $140^{\circ} \mathrm{C}$ and pressure of $0.35 \mathrm{MPa}$, is much milder compared to other upgrading methods. The addition of low sulfur wax residue (LSWR) of about $1 \%$ is very important to prevent the reabsorption of moisture. Using an Indonesian low-rank coal of Berau, results indicate that the UBC process can produce upgraded coals with better combustion characteristics compared to those of raw coals i.e., low tendency to self-ignition which is shown by a lower Tig, a lower Tmax and a higher Tmax. (Umar, Santoso and Usui, 2007).

Hydro thermal dewatering (HTD) process, also known as hot water drying (HWD) technology is a typical non-evaporative dewatering process (Ge et al., 2015). In the HTD process, the temperature is typically between 200 and $350^{\circ} \mathrm{C}$ (Mursito et al., 2010; Nonaka, Hirajima and Sasaki, 2011; Zhang et al., 2016), and the vessel pressure generated autogenously to stop the water from evaporating (Katalambula and Gupta, 2009). A particular advantage of the HTD is that most of the water is removed as a liquid, saving the energy that in some other drying techniques has to be used to evaporate the water (Liao et al., 2016). Because of these unique features, some researchers has extensively studied the HTD to improve LRCs characteristics (Mursito, Hirajima and Sasaki, 2011; Wu et al., 2015). Umar, (2015, 2016) and Umar, Shimojo and Madiutomo (2018) reported the effect of HTD process on combustion characteristics by some LRCs from Berau, Tabang, Samuranggau and Bunyu coals which were located in East Kalimantan and Banko coal in South Sumatra. The result also shows that the processed coal had better combustion characteristics and a lower tendency to selfcombustion.

An upgrading technique by steam drying originally patented by Fleissner in 1927, and developed by Koppelman in 1977 (Umar, 2019). Drying coal in steam offers reduction of fire and explosion hazards, and also improved the thermal efficiency (Chen, Agarwal and Agnew, 2001).This process removes the significant amounts of moisture from the low rank coal using heat and pressure. In simple terms, the low rank coal cooked and aged so that the product becomes similar to that of bituminous coal. The main advantage of this technology is the quality and stability of the upgraded coal compared to the raw coal or upgraded coal by other methods (Niksa and Krishnakumar, 2015), while superheated steam drying (SSD) is the drying of LRC with steam. In this process, there is a direct contact between the LRC and the superheated steam. The possibility of ignition and explosion during the LRC drying process can be avoided due to the inertia of superheated steam. In the case of power plants using LRC as fuel in a boiler, steam from the turbine can be used as drying medium. Hence, a drying by superheated steam has an energy saving potential (Godfrey, 2010). In the past studies, the low rank coal upgrading by a steam drying method have been investigated to study the effect of temperature process on the behavior of the upgraded coals using a Berau coal. The 
investigated processing temperatures ranged from $225^{\circ} \mathrm{C}$ to $300^{\circ} \mathrm{C}$. The least moisture content was achieved at the processing temperature of $300^{\circ} \mathrm{C}$ (Umar et al., 2005).

The main goal of this research is to understand the influence of coal upgrading by steam drying on combustion behavior. Both raw and upgraded coals were evaluated by thermal analysis techniques to obtain the combustion performance at high temperatures and heating rates using a DTA/TGA apparatus. It measures both heat flow (DTA) and weight changes (TG) in the coal as a function of temperature or time in a controlled atmosphere. The properties of chemical properties based on proximate, ultimate, calorific value analyses and Fourier-transform infrared (FTIR) spectroscopy, which are related to some combustion problems due to the drying process were also examined (Umar, Shimojo and Madiutomo, 2018).

\section{METHOD}

\section{Coal Upgrading}

This research used coal samples from Tabang, Kutai Kartanegara Regency (TKK) and Samurangau, Paser Regency (SP) of East Kalimantan. The coal was dried and screened through $\pm 25 \mathrm{~mm}$ in size (Umar et al., 2005). The steam drying process used an autoclave with a capacity of $5 \mathrm{l} / \mathrm{batch}$. The coal of about 200 grams was put into the autoclave, heat with steam at a temperature of $300^{\circ} \mathrm{C}$ and a pressure of about $5.5 \mathrm{MPa}$ for 1 hour. Then the autoclave was chilled and the upgraded coal was removed to study the effect of the process on the coal characteristic and combustion behaviors.

The proximate analysis covered the determination of moisture, ash and volatile matter and the calculation of fixed carbon according to the ASTM D.3173, D.3174, ISO 562 and ASTM D.3172. The ultimate analysis of carbon, hydrogen and nitrogen was based on the ASTM D. 5373, the total sulphur and the calculation of oxygen was according to ASTM D 4239 and ASTM D.3176, while the calorific value content was based on ASTM D.5865. The analyses were carried out to both coal samples before and after drying process.
The moisture content data of the raw and dried coals were used to evaluate the drying degree (Umar, Shimojo and Madiutomo, 2018).

$\mathrm{DD}: \frac{\mathrm{M} \text { raw coal }-\mathrm{M} \text { dried coal }}{\mathrm{M} \text { raw coal }} \times 100 \%$

Where DD is degree of dewatering and $M$ is the moisture content (\%) in the coals in the air dried basis.

\section{Functional Groups}

A Fourier transform infrared (FTIR) spectroscopy, HORIBA FT-720 in resolution of $1 \mathrm{~cm}^{-1}$ was used to study the change in functional group properties caused by the steam drying processes. FTIR as a nondestructive technique is one of the most powerful techniques to characterize the chemical structure of coal. It also provides fast comprehensive information on the functional groups in coal. The sample was measured by a $\mathrm{KBr}$ pellet method. The pellet used for the test was prepared from a mixture of $1 \mathrm{mg}$ coal and $100 \mathrm{mg} \mathrm{KBr}$ (Zhang et al., 2016). The measuring region ranges from 4000 to $400 \mathrm{~cm}^{-1}$. For each spectrum, 32 scans were accumulated.

The FTIR spectra were identified based on the available FTIR reference spectra on the World Wide Web. The characteristic of the absorption peaks are mainly in $3700-3000$, $3000-2800,1800-1000$, and $900-700 \mathrm{~cm}^{-1}$ except for negligible peaks in 2800-1800 $\mathrm{cm}^{-1}$, which are mainly due to the absorbance of $\mathrm{CO}_{2}$. The broad absorption band between $3700 \mathrm{~cm}^{-1}$ and $3000 \mathrm{~cm}^{-1}$ in coal is mainly due to the $\mathrm{O}-\mathrm{H}$ groups. The $3000-2800 \mathrm{~cm}^{-1}$ region is attributed to the absorption of aliphatic species. The region of 1800-1000 $\mathrm{cm}^{-1}$ observed in the spectrum is for absorption of complex hybrid portions such as $\mathrm{C}=\mathrm{O}$ vibration modes, aromatic $\mathrm{C}=\mathrm{C}, \mathrm{CH}_{3}$ bending, and C-O bonds (Tian et al., 2016).

The following parameters were defined as the ratio of de-convoluted peak area, $\mathrm{R}_{\mathrm{CH}} / \mathrm{CH} 2$, Raral, RcooH/ar, and Rco/ar, as the ratios of methyl/methylene of $2965 \mathrm{~cm}^{-1}$ band/2920 $\mathrm{cm}^{-1}$ band, aromatic/aliphatic of $1615 \mathrm{~cm}^{-1}$ band/(total of 2965, 2920, 2895, 2875, 2850 $\mathrm{cm}^{-1}$, five bands), carboxyl/aromatic of 1710 $\mathrm{cm}^{-1}$ band $/ 1615 \mathrm{~cm}^{-1}$ band, and carbonyl/aromatic of (total of 1770, 1710, $1700,1655 \mathrm{~cm}^{-1}$, four bands) $/ 1615 \mathrm{~cm}^{-1}$ band 
respectively. Carbonyl groups include ester, carboxyl, and other carbonyl group such as ketone (Liu, Duan and Ma, 2015).

\section{Combustion Characteristics}

The characteristics of coal combustion are required to assist in designing and maintaining the boiler. The design helps to maximize combustion efficiency and assists in reducing carbon particle emissions. Thermal analysis data can be applied to both of the characterization of different coal, and the evaluation of combustion performance at high temperatures and heating rates (Parshetti et al., 2014).

The DTA and TGA, respectively monitor the rate of mass loss and the relative mass loss as a function of temperature which is useful tool to study combustion behavior of coal since only a small size of the sample is required (Ávila et al., 2017). The combustion profiles are useful to evaluate the burning properties of fuel in a small amount of samples available or when it is impractical to test large quantities of fuel at existing installation (Marinov et al., 2010).

The DTA-TGA analysis was carried out using a Shimadzu DTG-60 apparatus. About $5 \mathrm{mg}$ sample performing particle size less than 75 $\mu \mathrm{m}$ (passed through 200 mesh screens) was placed in a platinum cell at an airflow rate of
$25 \mathrm{ml} / \mathrm{min}$ and heating rate of $10^{\circ} \mathrm{C} / \mathrm{min}$. The maximum experimental temperature was $800^{\circ} \mathrm{C}$ (Cheng et al., 2014).

The weight of loss sample and the rate of weight loss were recorded continuously as a function of time or temperature. All of the experiments were performed at atmospheric pressure, under an inert air. The combustion profiles obtained have various characteristic parameters as follows (Marinov et al., 2010):

$\operatorname{Tig}\left({ }^{\circ} \mathrm{C}\right) \quad$ : ignition temperature at which the weight loss curve (TGA) of from the baseline the coal combustion is departed;

$\operatorname{Tmax}\left({ }^{\circ} \mathrm{C}\right)$ : peak temperature of maximum heat flow (DTA);

Tbo $\left({ }^{\circ} \mathrm{C}\right) \quad$ : end of combustion temperature at which the rate of heat flow is zero (DTA);

$\operatorname{Rmax}(\mathrm{mg} / \mathrm{s})$ : defined as $[\mathrm{d}(\mathrm{TGA}) / \mathrm{dt}] \mathrm{T}=\mathrm{Tmax}$

The determination of the combustion parameters as above is illustrated in TGADTA profiles of Figure 1.

The heat released during combustion process, which correspond to the high heating value of coal, is estimated using the area under the DTA curve (Mahidin et al., 2003). In this study, the relationship of the high heating value calculated (HHVcalc, $\mathrm{MJ} / \mathrm{kg})$ and area under DTA curve, $A(\mu \mathrm{V}$. $\mathrm{sec}$ ).

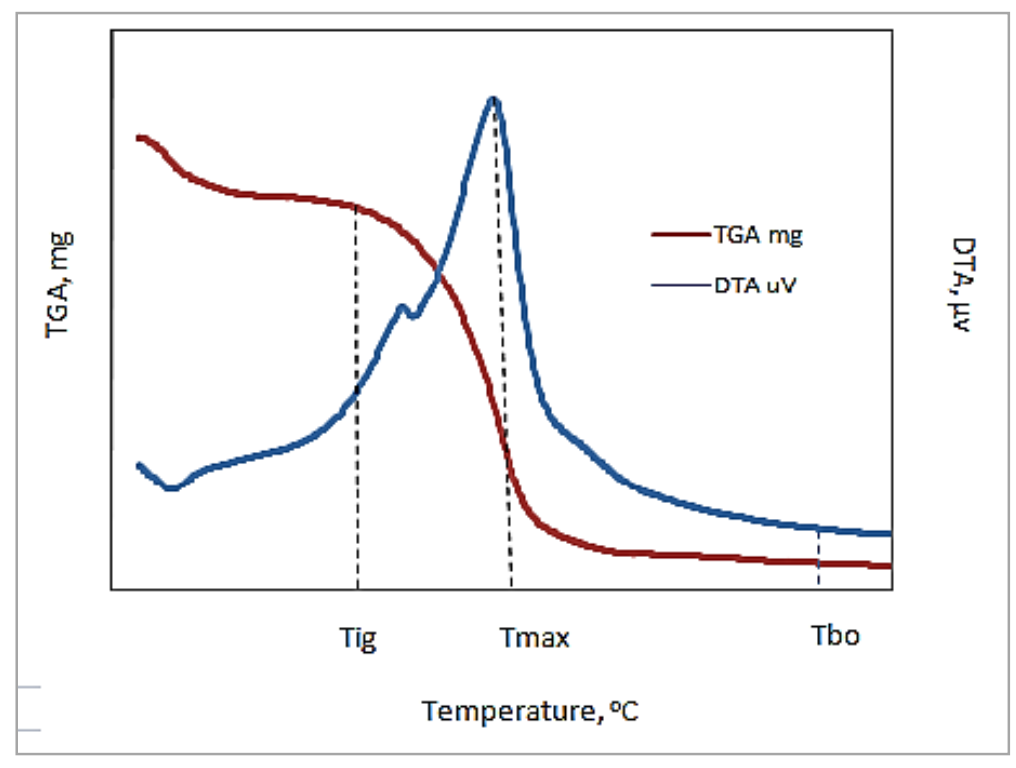

Figure 1. TGA-DTA profiles 


\section{RESULTS AND DISCUSSION}

\section{Chemical Characteristics of Dried Coals}

The proximate and ultimate analyses, including the calorific value of the raw and dried coals which were produced by steam drying process in a laboratory scale, can be seen in Table 1.

Table 1 shows that the dried coals, through the steam drying process, the moisture contents of both TKK and SP coals decreased significantly from $15.35 \mathrm{wt} \%$ to be $1.63 \%$ of the TKK coal and from 22.38 to be $1.82 \%$. The moisture in coals was removed in three ways:

- Removed by the thermal effects;

- Removed by the carbon dioxide generated by the thermal destruction of functional groups;

- Removed by the shrinkage and collapse effects of the coal (Ge et al., 2015).

The finding confirms that the inherent moisture removed irreversibly and that the water-holding capacity of coal decreases after the steam drying process.

All coal contains mineral matter, namely and will remain as the ash if the coal is burned. The presence of mineral matter in the coal is crucial in all aspects, from mining to utilization. Ashforming material varies significantly in number and distribution. There are two forms of mineral matter found in coal. The first is inherent mineral matter that is integrated with coal and inseparable and is formed from chemical elements present in plants from which the coal formed. The second is an extraneous mineral matter, ash-forming material originating from outside coal-forming plants and then is settled into coal fractures after coal formation. A washing process easily removes the extraneous mineral matter. From this point of view, the steam drying process at high temperature and pressure removed the extraneous mineral matter from coal. The SP coal has relatively low ash content $(2.76$ wt\% $\mathrm{db})$ and the ash reduction after steam drying process was not significant $(2.72 \mathrm{wt} \% \mathrm{db})$. It might due to the ash of SP coal is categorized as an inherent mineral matter. Only chemical extraction could remove this type of ash (Fujitsuka, Ashida and Miura, 2013). The ash content of the TKK coal decreases significantly from $5.22 \%$ to $2.57 \mathrm{wt} \%$ in dry basis. The type of ash in the TKK coal is categorized as an extraneous mineral matter which was easy to be removed by a steam process. The removal of ash, as well as moisture content, results in the increase of the calorific value of the TKK coal from 5,431 to $6,800 \mathrm{kcal} / \mathrm{kg}$ and the SP coal from 5,048 to $6,517 \mathrm{kcal} / \mathrm{kg}$.

The volatile matter of the coals decreased, whereas the fixed carbon content and CV of all upgraded coals increased significantly increased. The provided evidence, namely the active chemical components in the volatile matter had gradually transferred into stable compositions in the coal structure. These results indicate that the process promotes LRC carbonization and volatile matter decomposition, thereby resulting in enhanced LRC energy density (Ge et al., 2015).

Table 1. Analysis results of raw and dried coals

\begin{tabular}{lrrrr}
\hline \multirow{2}{*}{ Parameters } & \multicolumn{2}{c}{ TKK Coal } & \multicolumn{2}{c}{ SP Coal } \\
\cline { 2 - 5 } & \multicolumn{1}{c}{ Raw } & \multicolumn{1}{c}{ Dried } & \multicolumn{1}{c}{ Raw } & \multicolumn{1}{c}{ Dried } \\
\hline Inherent moisture, wt\% adb & 15.35 & 1.63 & 22.38 & 1.82 \\
Ash, wt\% db & 5.22 & 2.57 & 2.77 & 2.72 \\
Volatile matter, wt\% db & 48.06 & 40.59 & 48.99 & 40.91 \\
Fixed carbon, wt\% db & 46.72 & 56.84 & 48.24 & 56.37 \\
Carbon, wt\% daf & 72.46 & 76.07 & 71.55 & 73.76 \\
Hydrogen, wt\% daf & 5.48 & 5.18 & 5.95 & 5.83 \\
Nitrogen, wt\% daf & 0.97 & 0.92 & 0.92 & 0.82 \\
Sulphur, wt\% daf & 0.18 & 0.21 & 0.13 & 0.17 \\
Oxygen wt \% daf (by diff) & 20.92 & 17.63 & 21.45 & 19.42 \\
High heating value kcal/kg, adb & 5,431 & 6,800 & 5,048 & 6,517 \\
High heating value MJ/kg, adb & 22.72 & 28.45 & 21.12 & 27.27 \\
O/C & 0.29 & 0.23 & 0.30 & 0.26 \\
H/C & 0.08 & 0.07 & 0.08 & 0.08 \\
Degree of dewatering, \% & 89.38 \\
\hline Note: adb: arryyyyyy dred basis & \multicolumn{3}{c}{91.87} & \\
\hline
\end{tabular}
$\begin{array}{ll}\text { Note: } & \text { adb: air dried basis } \quad \mathrm{db} \text { : dry basis } \\ & \text { daf: dry ash free }\end{array}$ 
These results were also in line with the ultimate analysis which showed that the carbon contents increased, whereas the oxygen contents decreased. The decrease was also shown in atomic ratios of oxygen to carbon $(\mathrm{O} / \mathrm{C})$ of the coal samples after steam drying process, whereas the hydrogen to carbon $(\mathrm{H} / \mathrm{C})$ was slightly decreased or relatively constant. The reduction of oxygen described as the reduction and dehydration reactions (Zhang et al., 2016).

\section{Functional Group Analysis of Dried Coals}

The effect of the drying process on the FTIR spectra obtained from the raw and dried coals is shown in Figures 2. The infrared spectra of the coals are divided into four regions, namely hydroxyl with peaks appearing in the range of $3600-3000 \mathrm{~cm}^{-1}$, peaks in the range of $3000-2700 \mathrm{~cm}^{-1}$ that belong to aliphatic, the peaks in $1800-1000 \mathrm{~cm}^{-1}$ which correspond to functional groups and aromatic, while the aromatic in the low wave region and ash matter considered in the peaks of 900-700 $\mathrm{cm}^{-1}$ (Zodrow et al., 2012; Ge et al., 2015).
Table 2 summarized the spectrum parameters of the raw and dried coals.

Table 2. Parameters based on FTIR spectrum of raw and dried coals

\begin{tabular}{lccc}
\hline \multicolumn{1}{c}{ Coals } & $\mathrm{R}_{\mathrm{CH} 3 / \mathrm{CH} 2}$ & $\mathrm{R}_{\mathrm{CO} / \mathrm{ar}}$ & $\mathrm{R}_{\text {ar/al }}$ \\
\hline TKK & & & \\
Raw & 0.09 & 0.32 & 2.30 \\
SD & 0.18 & 0.17 & 3.32 \\
\hline SP & & & \\
Raw & 0.04 & 0.31 & 3.51 \\
SD & 0.16 & 0.24 & 5.50 \\
\hline
\end{tabular}

The $\mathrm{CH}_{3} / \mathrm{CH}_{2}$ measures the length of aliphatic chains and the degree of branching of aliphatic side chains attached to the macromolecular structure of the coal (Wang, Chen and Zhang, 2020). The $\mathrm{R}_{\mathrm{CH}} / \mathrm{CH}_{2}$ ratio were increased for both of the coals. Higher $\mathrm{R}_{\mathrm{CH} / \mathrm{CH} 2}$ values indicate longer and less branched aliphatic chains, the reduction and destruction of the bridge bond connecting with $\mathrm{CH}_{2}$, and an improvement in the coal rank values (Ge et al., 2015).

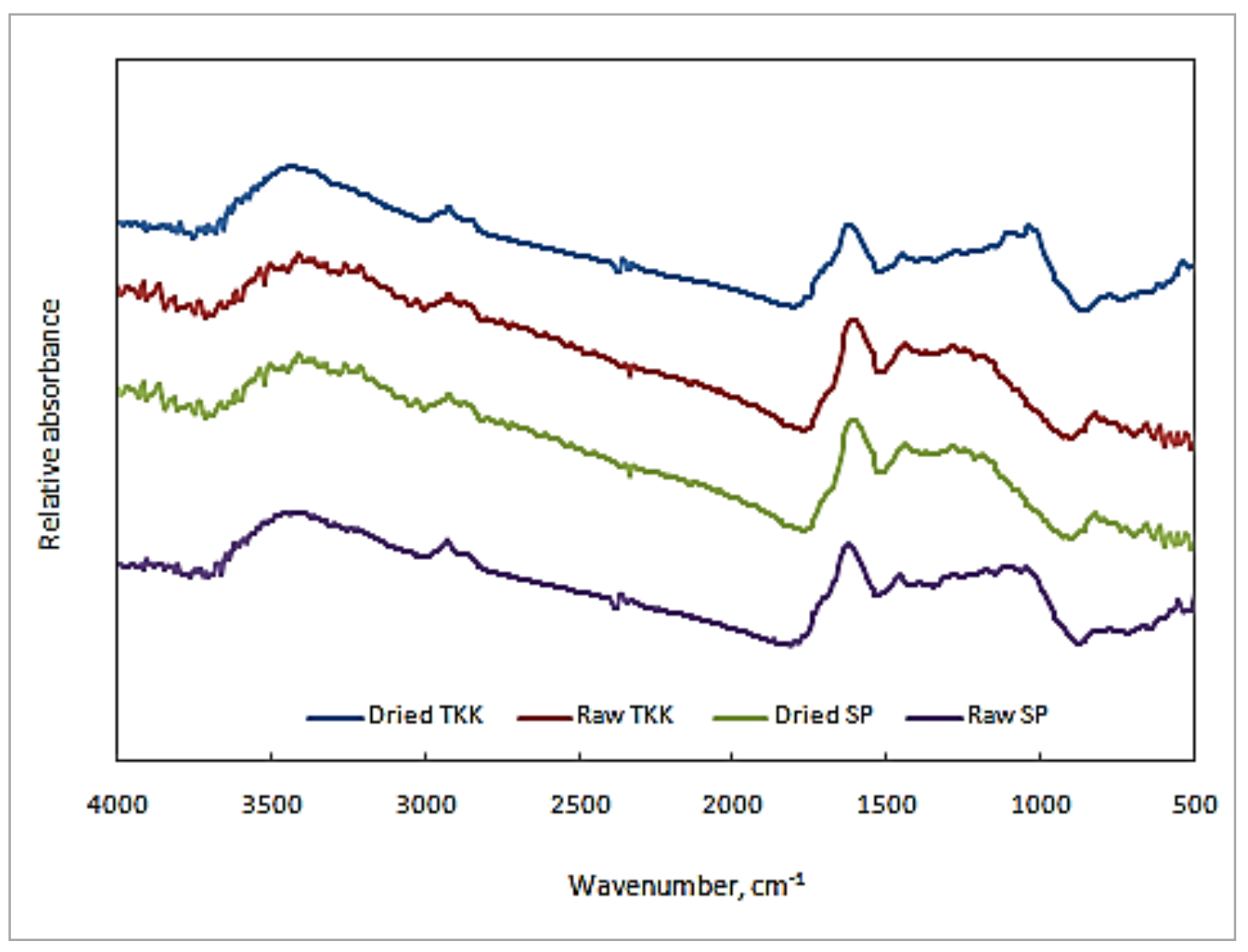

Figure 2. . FTIR spectra of raw and dried coals 
Carbonyl/aromatic (Rco/ar) represents the dissociation and shift of oxygen functional groups. The dried coals have lower Rco/ar values than that of the raw coals. According to Ahmed (2003), coal with lower Rco/ar indicates the decrease in the carbonyl or carboxyl groups to aromatic carbon groups, reduction and destruction of oxygen functional groups during the drying process. The lesser the ratio of carbonyl or carboxyl groups to aromatic carbon groups, the higher the rank of coal (Suggate and Dickinson, 2004). The aromatic/aliphatic $\left(R_{a r} / R_{a l}\right)$, another parameter related to the aromaticity and grade of coal rank of the dried coals, increased. Higher value of $R_{a r} / R_{a l}$ indicates higher aromaticity and maturity that shows that the coal rank is increasing ( $\mathrm{Ge}$ et al., 2015).

\section{Combustion Behavior of Dried Coals}

Figure 3 shows the TGA-DTA curves of the raw and dried coals. The curves are illustrated heat differentiation during the test. The TG curves of the raw and dried coals showed a relative weight loss. The weight loss under 150 ${ }^{\circ} \mathrm{C}$ is associated with the removal moisture within the coal, and above $150^{\circ} \mathrm{C}$ is related to the combustion of volatiles and charcoal. It shows that the TG curves of both raw coals at the temperature about $50-100^{\circ} \mathrm{C}$ sharply decreased due to the high moisture content. While the dried coals in the profile of TG curve at such the temperature decreased slightly. These profiles indicate that the moisture content of the dried coals decreases due to the steam drying process. Several parameters derived from TG-DTA analysis are summarized in Table 3.

The Tig value corresponds to the ignition temperature of the volatile matter. The Tig is an important preliminary step in the coal combustion process due to its influence on the formation and emission of pollutants, flame stability, and flame extinction (Sahu et al., 2010). The Tig of both of the dried coals was increased. The higher the Tig, the lower the volatile matter. These results are in line with the volatile matter content, as shown in Table 1. In general, the coal with low ignition temperature can be considered easy to ignite or has a high tendency to be self-ignition.
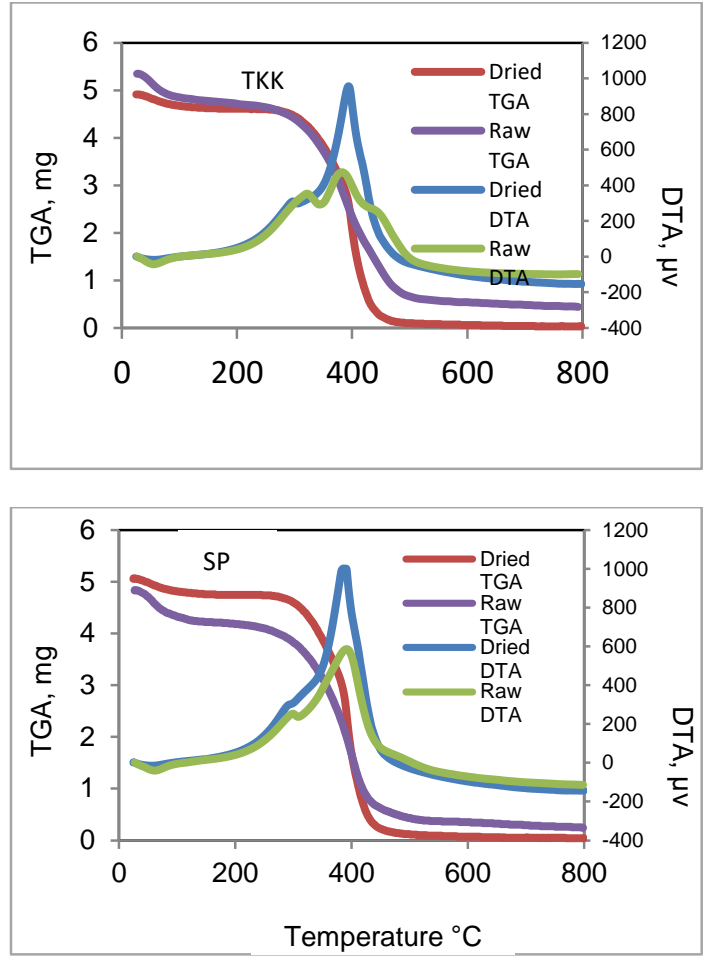

Figure 3. DTA-TGA curves of the raw and dired coals

Table 3. Combustion parameter of raw and dried coals

\begin{tabular}{lcccc}
\hline Coals & $\begin{array}{c}\text { Tig } \\
{ }^{\circ} \mathrm{C}\end{array}$ & $\begin{array}{c}\text { Tmax } \\
{ }^{\circ} \mathrm{C}\end{array}$ & $\begin{array}{c}\text { Rmax } \\
\mathrm{mg} / \mathrm{min}\end{array}$ & $\mathrm{Tbo}^{\circ} \mathrm{C}$ \\
\hline TKK & & & & \\
Raw & 252 & 381 & 0.25 & 789 \\
SD & 283 & 393 & 0.49 & 785 \\
\hline SP & & & & \\
Raw & 249 & 392 & 0.31 & 789 \\
SD & 277 & 385 & 0.56 & 793 \\
\hline
\end{tabular}

The DTA curves show the evolution of heat flow with elevated temperatures. The first part of the DTA curves corresponds to a global endothermic process, which is the result of heat adsorption (endothermic) and oxidation reactions (exothermic). There were three DTA peaks for all coals. The first peak (heating loss, $\mu \mathrm{v}$ ) corresponds to a global endothermic process, which appeared at about 60 to $100^{\circ} \mathrm{C}$, as a result of water vaporization. The raw coals peak was higher compared to those of the dried coals due to the higher moisture content. The second peak, corresponded to the removal of volatile matter was slightly decreased. Furthermore, the third peak that showed the highest, exhibit exothermic 
events during the entire combustion test at the temperatures higher than $350^{\circ} \mathrm{C}$. Both of the dried coals significantly increased. It characterized that the major took heat released in the combustion of dried coals place. Based on this fact, it seems that the heating values of the dried coals were higher than that of the raw coals as shown in Table 1.

Tmax is related to coal reactivity. Reactive coals have lower Tmax and can generally be ignited and burned more easily. Such coals would expect to burn more completely in the lower part of a boiler furnace, while coals exhibiting high Tmax burn relatively slow and would require longer residence times or higher temperatures for complete combustion (Ávila et al., 2017). Table 3 shows that the Tmax of TKK dried coal increased while the SP coal decreased due to the steam drying process. The Tmax of the SP coal after SD process decreased possibly due to its high moisture content (Ge et al., 2015).

The Rmax indicates the maximum combustion rate, defined as the weight loss to the time at the temperature maximum $[\mathrm{d}(\mathrm{TGA}) / \mathrm{dt}]_{\mathrm{T}=\mathrm{Tmax}}$. The Rmax of the dried upgraded coals was higher than that of the raw coals. It expressed that the dried coals were easy to be burnt due to high calorific value and less moisture content (Song et al., 2017).

From the DTA curve, it is possible to determine the end of combustion (Tbo). This is corresponded to the temperature when the rate of heat flow is zero (Marinov et al., 2010). The Tbo reflects the char characteristic. Low Tbo reflects right burnout property. The Tbo of the dried TKK coal decreased while the dried SP coal slightly increased due to the steam drying process. These results are in line with the Tmax results.

To determine the high heating value (HHV) of coal, in this study, the relationship of the high heating value calculated (HHVcalc, MJ/kg) and area under DTA curve, $A(\mu \mathrm{V}$. sec) and TGAi (initial weight) is represented according to the equation of $16.09511+(1.1 .10$ $\left.{ }^{5} \mathrm{XA} / \mathrm{TGAi}\right)$. The experiment and measured of the HHV can be seen in Table.4.

The HHVs calculated from DTA analysis were different from the HHVs measured using a bomb calorimeter according to the ASTM Standard D-3286 (Table1). Deviation of equation and accuracy in determining the area under the DTA peaks caused these differences. Table 4 shows that HHV of the dried coals was higher rather than that of the raw coals which aligns with the higher peaks of the dried coals.

Table 4. Calculated and measured HHV of the raw and upgraded coals

\begin{tabular}{lccll}
\hline Coals & $\begin{array}{l}\text { DTA } \\
\text { max } \\
\text { peak, } \\
\mu v\end{array}$ & $\begin{array}{l}\text { A/TGAi, } \\
\text { sec/mg }\end{array}$ & $\begin{array}{l}\text { HHV } \\
\text { measured } \\
\text { MJ/kg }\end{array}$ & $\begin{array}{l}\text { HHV } \\
\text { calc. } \\
\text { MJ/kg }\end{array}$ \\
\hline TKK & & & & \\
Raw & 437 & 53,270 & 22.72 & 23.25 \\
Dried & 957 & 84,859 & 28.45 & 27.95 \\
\hline SP & & & & \\
Raw & 585 & 74,640 & 21.12 & 21.35 \\
Dried & 1001 & 105,376 & 27.27 & 28.10 \\
\hline
\end{tabular}

\section{CONCLUSION}

The results indicate that the steam drying process can upgrade the low-rank coal. The calorific value of TKK coal increased significantly from $5,431 \mathrm{kcal} / \mathrm{kg}$ to 6,800 $\mathrm{kcal} / \mathrm{kg}$, while the SP coal from $5,048 \mathrm{kcal} / \mathrm{kg}$ to $6,517 \mathrm{kcal} / \mathrm{kg}$ in air-dried basis, mostly due to the decreased of moisture content. The degree of dewatering was $89.38 \%$ from TKK and $91.87 \%$ from SP coals respectively. The FTIR spectrum obtained for the raw and dried coals shows that the $\mathrm{R}_{\mathrm{CH} 3 / \mathrm{CH} 2}$ and $\mathrm{R}_{\text {ar/al }}$ value of the dried coals increased and the Rco/ar decreased due to the drying processes which reflects improvement of rank coals. In this study, the Tig of both of the dried coals increased as well as the Rmax. It expressed that the dried coals have better combustion behavior which was easier to be burnt due to higher calorific value and less moisture content than the raw coals.

\section{ACKNOWLEDGEMENT}

The authors gratefully acknowledge the R\&D Centre for Mineral and Coal Technology (tekMIRA) for supporting this research. Thanks also go to the staff of coal laboratory of tekMIRA for their assistance during the laboratory tests. 


\section{REFERENCES}

Ahmed, M., Blesa, M. J., Juan, R. and Vandenberghe, R. B. (2003) "Characterisation of an Egyptian coal by

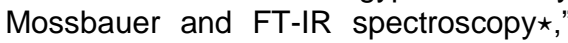
Fuel, 82(14), pp. 1825-1829. doi: 10.1016/S0016-2361(03)00131-5.

Ávila, I., Crnkovic, P. M., Luna, C. M. R. and Milioli, F. E. (2017) "Use of a fluidized bed combustor and thermogravimetric analyzer for the study of coal ignition temperature," Applied Thermal Engineering, 114, pp. 984-992. doi: 10.1016/j.applthermaleng.2016.11.171.

Chen, Z., Agarwal, P. K. and Agnew, J. B. (2001) "Steam drying of coal. Part 2. Modeling the operation of a fluidized bed drying unit," Fuel, 80(2), pp. 209-223. doi: 10.1016/S0016-2361(00)00081-8.

Cheng, Q., Via, B., Wang, J. and Zondlo, J. (2014) "Primary study of woody biomass and coal for energy production investigated by TGA-FTIR analysis," BioResources, 9(2). doi: 10.15376/biores.9.2.2899-2906.

Deguchi, T., Shigehisa, T. and Shimasaki, K. (1999) "Study on upgraded brown coal process for Indonesian low rank coals," in Proc. International Conference on Clean and Efficient Coal Technolgy in Power Generation. Indonesia, pp. 176-180.

Fei, Y., Aziz, A. A., Nasir, S., Jackson, W. R., Marshall, M., Hulston, J. and Chaffee, A. L. (2009) "The spontaneous combustion behavior of some low rank coals and a range of dried products," Fuel, 88(9), pp. 1650-1655. doi: 10.1016/j.fuel.2009.03.017.

Fujitsuka, H., Ashida, R. and Miura, K. (2013) "Upgrading and dewatering of low rank coals through solvent treatment at around $350^{\circ} \mathrm{C}$ and low temperature oxygen reactivity of the treated coals," Fuel, 114, pp. 16-20 doi: 10.1016/j.fuel.2012.12.010.

Ge, L., Zhang, Y., Xu, C., Wang, Z., Zhou, J. and Cen, K. (2015) "Influence of the hydrothermal dewatering on the combustion characteristics of Chinese low-rank coals," Applied Thermal Engineering, 90, pp. 174-181. doi: 10.1016/j.applthermaleng.2015.07.015.

Godfrey, B. (2010) "Recent developments in innovative drying technologies," in International Symposium on the Sustainable Use of Low Rank Coals.
Melbourne, Australia: The Department of Primary Industries (DPI), p. 31.

Katalambula, H. and Gupta, R. (2009) "Low-grade coals: A review of some prospective upgrading technologies," Energy \& Fuels, 23(7), pp. 3392-3405.

doi: $10.1021 /$ ef801140t

Liao, J., Fei, Y., Marshall, M., Chaffee, A. L. and Chang, L. (2016) "Hydrothermal dewatering of a Chinese lignite and properties of the solid products," Fuel, 180 , pp. 473-480. doi: 10.1016/j.fuel.2016.04.027.

Liu, M., Duan, Y. and Ma, G. (2015) "The effect of organic solvent thermal treatment on the physicochemical properties of lignite," Asia-Pacific Journal of Chemical Engineering, 10(5), pp. 724-733. doi: 10.1002/apj.1910.

Mahidin, Ogaki, Y., Usui, H. and Okuma, O. (2003) "The advantages of vacuum-treatment in the thermal upgrading of low-rank coals on the improvement of dewatering and devolatilization," Fuel Processing Technology, 84(1-3), pp. 147-160. doi: 10.1016/S0378-3820(03)00052-3.

Marinov, S. P., Gonsalvesh, L., Stefanova, M., Yperman, J., Carleer, R., Reggers, G., Yürüm, Y., Groudeva, V. and Gadjanov, P. (2010) "Combustion behaviour of some biodesulphurized coals assessed by TGA/DTA," Thermochimica Acta, 497(1-2), pp. 46-51. doi: 10.1016/j.tca.2009.08.012.

Mursito, A. T., Hirajima, T., Sasaki, K. and Kumagai, S. (2010) "The effect of hydrothermal dewatering of Pontianak tropical peat on organics in wastewater and gaseous products," Fuel, 89(12), pp. 3934-3942. doi: 10.1016/j.fuel.2010.06.035

Mursito, A. T., Hirajima, T. and Sasaki, K. (2011) "Alkaline hydrothermal de-ashing and desulfurization of low quality coal and its application to hydrogen-rich gas generation," Energy Conversion and Management, 52(1), pp. 762-769. doi: 10.1016/j.enconman.2010.08.001.

Niksa, S. and Krishnakumar, B. (2015) "Predicting the steam drying behavior of brown coals and lignites," Fuel, 159, pp. 345-353. doi: 10.1016/j.fuel.2015.06.031.

Nonaka, M., Hirajima, T. and Sasaki, K. (2011) "Upgrading of low rank coal and woody biomass mixture by hydrothermal 
treatment," Fuel, 90(8), pp. 2578-2584. doi: 10.1016/j.fuel.2011.03.028.

Parshetti, G. K., Quek, A., Betha, R. and Balasubramanian, R. (2014) "TGA-FTIR investigation of co-combustion characteristics of blends of hydrothermally carbonized oil palm biomass (EFB) and coal," Fuel Processing Technology, 118, pp. 228234. doi: 10.1016/j.fuproc.2013.09.010.

Rao, Z., Zhao, Y., Huang, C., Duan, C. and He, J. (2015) "Recent developments in drying and dewatering for low rank coals," Progress in Energy and Combustion Science, 46, pp. 1-11. doi: 10.1016/j.pecs.2014.09.001

Sahu, S. G., Sarkar, P., Chakraborty, N. and Adak, A. K. (2010) "Thermogravimetric assessment of combustion characteristics of blends of a coal with different biomass chars," Fuel Processing Technology, 91(3), pp. 369378. doi: 10.1016/j.fuproc.2009.12.001.

Sakaguchi, M., Laursen, K., Nakagawa, H. and Miura, K. (2008) "Hydrothermal upgrading of Loy Yang Brown coal Effect of upgrading conditions on the characteristics of the products," Fuel Processing Technology, 89(4), pp. 391396. doi: 10.1016/j.fuproc.2007.11.008.

Shigehisa, T., Deguchi, T., Shimasaki, K. and Makino, E. (2000) "Development of UBC process," in Proc. International Conference on Fluid and Thermal Energy Conversion. Indonesia, p. 16.

Song, H., Liu, G., Zhang, J. and Wu, J. (2017) "Pyrolysis characteristics and kinetics of low rank coals by TG-FTIR method," Fuel Processing Technology, 156, pp. 454460. doi: 10.1016/j.fuproc.2016.10.008.

Suggate, R. P. and Dickinson, W. W. (2004) "Carbon NMR of coals: the effects of coal type and rank," International Journal of Coal Geology, 57(1), pp. 1-22. doi: 10.1016/S0166-5162(03)00116-2.

Tian, B., Qiao, Y., Tian, Y., Xie, K., Liu, Q. and Zhou, H. (2016) "FTIR study on structural changes of different-rank coals caused by single/multiple extraction with cyclohexanone and NMP/CS 2 mixed solvent," Fuel Processing Technology, 154, pp. 210-218. doi: 10.1016/j.fuproc.2016.08.035.

Umar, D. F., Daulay, B., Usui, H. and Suprapto, S. (2005) "Upgrading of indonesian low rank coal by steam drying method," Indonesian Mining Journal, 8(1), pp. 2126.

Umar, D. F. (2015) "Low rank coal upgrading: Effect of upgrading conditions on characterization of the product," in Proceedings of BIT's 4th Annual International Symposium of Clean Coal Technology (CCT 2015). Xián, China: CCT, p. 24.

Umar, D. F. (2016) "Sifat pembakaran batubara hasil proses upgrading dengan teknologi hot water drying," in Santoso, B. et al. (eds.) Prosiding Kolokium Puslitbang Teknologi Mineral dan Batubara 2016. Bandung: Puslitbang tekMIRA, pp. 4961.

Umar, D. F. (2019) "Low rank coal upgrading," in Sihombing, F. M. H. and Yulman, R. (eds.) Proceedings of The 11th MGEI Annual Convention "Unlocking Concealed and Complex Deposits." Bogor: IAGI \& MGEI, pp. 58-72.

Umar, D. F., Santoso, B. and Usui, H. (2007) "The Effect of Upgrading Processes on Combustion Characteristics of Berau Coal," Energy \& Fuels, 21(6), pp. 33853387. doi: 10.1021/ef070061j.

Umar, D. F., Shimojo, M. and Madiutomo, R. M. N. (2018) "Evaluation of combustion behaviour for Indonesian low-rank coals treated hydrothermally," Indonesian Mining Journal, 21(2), pp. 127-139. doi: 10.30556/imj.Vol21.No2.2018.919.

Umar, D. F., Usui, H. and Daulay, B. (2005) "Effects of processing temperature of hot water drying on the properties and combustion characteristics of an Indonesian low rank coal," Coal Preparation, 25(4), pp. 313-322. doi: $10.1080 / 07349340500444554$.

Wafid, M. (2019) "Country report-Indonesia," in 17th Afoc Council Meeting. Langkawi: AFOC.

Wang, S., Chen, H. and Zhang, X. (2020) "Transformation of aromatic structure of vitrinite with different coal ranks by HRTEM in situ heating," Fuel, 260, p. 116309. doi: 10.1016/j.fuel.2019.116309.

Wu, J., Liu, J., Zhang, X., Wang, Z., Zhou, J. and Cen, K. (2015) "Chemical and structural changes in XiMeng lignite and its carbon migration during hydrothermal dewatering," Fuel, 148, pp. 139-144. doi: 10.1016/j.fuel.2015.01.102. 
The Influence of Steam Drying Process on Combustion Behavior of Indonesia ... Datin F. Umar et al.

Yu, J., Tahmasebi, A., Han, Y., Yin, F. and Li, X. (2013) "A review on water in low rank coals: The existence, interaction with coal structure and effects on coal utilization," Fuel Processing Technology, 106, pp. 9-20.

doi: 10.1016/j.fuproc.2012.09.051.

Zhang, Y., Wu, J., Wang, Y., Miao, Z., Si, C., Shang, X. and Zhang, N. (2016) "Effect of hydrothermal dewatering on the physicochemical structure and surface properties of Shengli lignite," Fuel, 164, pp. 128133. doi: 10.1016/j.fuel.2015.09.055.

Zodrow, E. L., D'Angelo, J. A., Helleur, R. and Šimůnek, Z. (2012) "Functional groups and common pyrolysate products of Odontopteris cantabrica (index fossil for the Cantabrian Substage, Carboniferous)," International Journal of Coal Geology, 100, pp. 40-50. doi: 10.1016/j.coal.2012.06.002. 
